Institute of $\mathbf{F}_{\text {ood and }} \mathbf{A g r i c u l t u r a l}_{\text {ciences }}$

\title{
Grandparents Raising Grandchildren: Navigating the System Part 1 - Community Resources ${ }^{1}$
}

Maisie Ross, Millie Ferrer, and Angela Falcone ${ }^{2}$
Goal: To provide

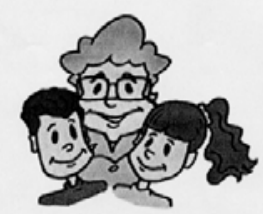

grandparents with information and skills necessary to use various community resources.
An increasing number of grandparents are caring for their grandchildren. There are many reasons for this. Whatever the reason, being a primary caregiver for your grandchild can be an overwhelming task. Those who take on the job are often in need of assistance with their new role. The following are some issues which many grandparents struggle with:
i financial
i childcare
i educational
i medical
i respite care
i emotional/support

Take some time to think about your own situation. Which issues are you struggling with as you take care of your grandchild?

One of the greatest challenges facing grandparent caregivers is knowing where to get help. If you are a grandparent who now has the primary role of caring for your grandchild, help is available.

Do you know what services are available in your area? Taking on this new parenting role should not lessen the quality of life for you or your grandchild. It should not use up all your savings. Both you and your grandchild are entitled to any assistance available in your community.

\section{Developing Your Plan}

Many grandparents are not aware of or are unable to effectively use community resources. If you want help, you will need to

1. This document is FCS 2188-Eng, one of a series of the Department of Family, Youth and Community Sciences, Florida Cooperative Extension Service, Institute of Food and Agricultural Sciences, University of Florida. Publication date: January 2002. Reviewed by Anne Fugate, Project Coordinator, University of Florida, for Florida's CYFAR State Strengthening Grant and Stephanie Toelle, Extension Agent III. Thanks to Erica Murphy, UF undergraduate student, for her support and assistance. Please visit the EDIS Web site at http://edis.ifas.ufl.edu

2. Maisie Ross, M.S., Extension Agent III, Millie Ferrer, Ph.D., Associate Professor, Human Development, and Angela Falcone, Ed.S., Graduate Assistant, Department of Family, Youth and Community Sciences, Cooperative Extension Service, Institute of Food and Agricultural Sciences, University of Florida, Gainesville, 32611. 
develop a plan of action which includes the following steps:

1. Identify and list the problems you are having.

2. Write down the barriers that are preventing you from getting the help you need.

3. Create a plan to search for available community resources that match your needs.

\section{Preparing for the Search}

It can be difficult and time consuming to search for needed resources. It is important that you think clearly about what you need and must do. You will need to learn how to work with public systems such as schools, child welfare, health, and legal aid. Keep in mind that many of these systems were not originally set up to recognize grandparents raising their grandchildren.

You can develop qualities to be better prepared for your search. According to the Grandparent Resource Center, you need to be...

1. Confident - If you qualify for a service, you have the right to use. Ask for what you need and say it with confidence.

2. Organized - People will take you more seriously if you are organized. You will be more effective if you...

- make a list of the agencies that best fit your needs.

- write down the phone number(s).

- locate a contact person.

- prepare questions to ask on the phone or in person.

- $\quad$ are on time for all appointments.
- write down what you were told and the name of the person with whom you met.

3. Persistent - Don't give up. Keep looking and asking questions. One person may tell you he can't help, but sure enough, someone else at the same agency can.

4. Energetic - Take care of yourself. Get enough rest so your mind will be alert. Be enthusiastic when you ask for and receive help.

5. Well Prepared - Have the following documents:

- your grandchild's birth certificate

- proof of caretaker responsibility, (e.g., a statement from the parent or any legal document)

- child's social security number

- proof of income for household members

- proof of ownership, (e.g., house deed, title of car)

- your household expenses, (e.g., mortgage payments or rent receipts, utility bills)

\section{Where to Search}

There are a number of resources available to you. These include government and private agencies. Some of these are universities, senior centers, and schools. You can also look for

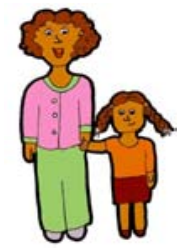
help in faith-based groups and support groups. Fees for these services range in price. Government services are usually free or cost very little.

As you search your community, you will find resources to assist you. These resources can 
help you with your financial, health, childcare, or educational needs. The remainder of this publication describes various community resources.

\section{Financial Assistance}

It is often difficult to house, feed,

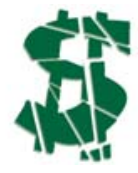
and clothe an added individual. This is more difficult when you are on a limited income. You and your grandchild may be entitled to receive financial assistance. Listed below are several of these programs.

\section{TANF (Temporary Assistance to Needy}

Families): This program offers financial assistance for low income families. There are different rules for receiving cash assistance. You may qualify to receive benefits as a family, or your grandchild can receive benefits under the child only grant. With the child only grant, your grandchild may be able to receive benefits until he* is 18 .

Relative Caregiver Program: This program provides monthly cash assistance and benefits for children living with relative caregivers. The amount of cash assistance depends upon the age of your grandchild. Payments are slightly higher than TANF. To qualify for this program...

- you must live in the State of Florida.

- your grandchild must be placed with you by the courts (adjudicated dependent).

- your grandchild must be younger than 18.

- you must agree to a background check and home study completed by the Department of Children and Families (DCF).
Food Stamps: The Food Stamp Program helps limited income families pay for food. When a family applies, this program considers...

- the total monthly household income of each adult.

- the value of items owned (not including your house).

- family expenses.

TANF, Relative Caregiver, and the Food Stamp programs are available through the Economic Services Program Office (850) $892-8600$. This service is provided by the Florida Department of Children and Families. You can find the local number in the blue pages of your telephone book.

\section{Supplemental Program for Women, Infants, and Children (WIC): WIC} provides a monthly food coupon packet that helps to improve the nutritional quality of a child's diet. It serves children under the age of 5 who are at risk of poor nutrition. If your family qualifies for Medicaid, Food Stamps, and TANF, you will very likely qualify for WIC. To apply for WIC, you will need to prove legal custody or guardianship of your grandchild. For more information on how to receive WIC benefits, call the Florida WIC Office at 1-800-342-3556.

Supplemental Security Income (SSI): This program pays monthly cash benefits to families with mentally or physically disabled children. To qualify, families need to have a limited income. For more information about this benefit contact the Social Security Office at 1-800-772-1213. 
Earned Income Tax Credit (EITC): You may qualify for EITC if you meet all of these criteria:

- your grandchild is under age 19 or under age 24 and is a full-time student

- your grandchild is disabled

- your grandchild has lived in your home for more than 6 months of the tax yea.

- you pay more than $50 \%$ of your grandchild's support and the child is not claimed as a dependent by the parent

- you have worked during the tax year

Contact the Internal Revenue Service (IRS) at 1-800-829-1040, or look for a local number in the blue pages of your telephone book.

\section{Health Care Assistance}

You have many options for health care coverage. These options include private insurance, Medicaid, Head Start, and Florida KidCare. Private insurance is the most expensive option.

Medicaid: Medicaid provides health care coverage to families with low incomes. Some of the benefits it pays for are physical, mental, and dental health care. If your grandchild qualifies for TANF, Relative Caregiver Program, or Supplemental Security Income (SSI), he automatically qualifies for Medicaid. You will still need to apply separately through the Economic Services Program Office at DCF. When you contact them, let them know your grandchild is receiving other benefits.

Head Start/Early Head Start: Both of these programs have Family Service Specialists who will work with you to help you find proper health services in your community.
If your grandchild does not have health insurance, he can receive referrals for dental and medical attention through these programs. Check with your local Head Start program (see blue pages of phone book) to find the available resources in your area.

Florida KidCare: Florida KidCare has four different health programs. These programs are:

1. KidCare Medicaid - This is a program for children from birth through age 18 . To qualify, you must complete an application. Eligibility for this program is based on income.

2. MediKids - This is a program for children ages 1 through 4 who are not eligible for medicaid. There is a $\$ 15$

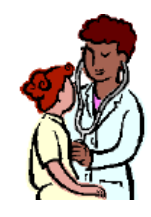
monthly premium.

3. Florida Healthy Kids - This program provides an all-round health insurance plan for school-age children (ages 5 through 18). Most families pay $\$ 15$ per month. If you earn more than the maximum allowable income, you may purchase this coverage at the full price. This program does not enroll children throughout the year. You must enroll during an "open enrollment period."

\section{Children's Medical Services Network} (CMS Network) - This is a health plan for children with special on-going health care needs. These include diabetes, leukemia, and behavioral health problems. It is for children under age 19 and provides medical services, supplies, therapies, and equipment. There is usually a $\$ 15$ monthly premium for this program. 
For more information on the Florida KidCare programs, call Florida KidCare at 1-888-5405437.

\section{Child Care Assistance}

Coping with the demands of caring for children on a daily basis can be very stressful. You may need to work at the same time you are caring for your grandchild. There are different agencies or groups in the community that provide child care or after-school care. To find out about your options for child care in your community, contact your local Child Care Resource \& Referral (CCR\&R) agency or $D C F$. The following are available statewide:

\section{Florida Partnership for School Readiness:}

Two different subsidized child care programs are available.

i Granny Grant: You do not need to have legal custody of your grandchild to apply for this child care program.

i Relative Care Giver Program: If you are receiving assistance through this program (see p. 2 for explanation), you can qualify for child care.

For more information on these and other subsidized child care programs, call the Florida Partnership for School Readiness (850) 488-0337 or Florida Children's Forum (888) 352-4453.

Head Start and Early Head Start: These are programs for children from birth to age five. They are child-focused programs aimed at increasing the school readiness of young children in low-income families. For more information, call your local Head Start Center.

Afterschool Care for Children: If you continue to work while raising your grandchild, you may be faced with the possibility of needing after-school care.

After school care can be found at:

- Schools

- Boys and Girls Clubs

- YMCA

- Places of Worship

- Parks and Recreation Department

- Private Centers

- Nonprofit Organizations

\section{Public School}

Registering your grandchild in public school is an important task. There are several documents you will need to have with you to register your grandchild for public school. You will need to show proof of

- your residence

- your grandchild's date of birth

- your grandchild's record of immunizations and physical exams

- custody

- any previous school records

If your grandchild has attended public school before, these documents may be on file at his previous school.

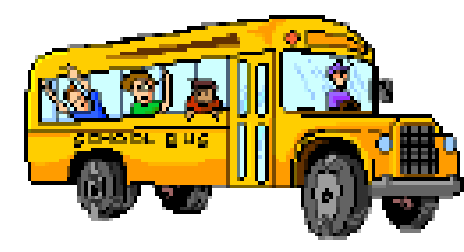

In addition to all the resources discussed so far, there are other agencies that can assist you with your new role of raising your grandchild. These include: 
AARP Grandparent Information Center

(202) 434-2296

e-mail: gic@aarp.org

The AARP offers a variety of resources, including tip sheets, newsletters, and referrals to help grandparents.

Kinship Care Warmline

(800) 640-6444

This toll-free line provides information, referrals, and emotional support to kinship caregivers.

United Way Information and Referral (800) 411-8929

This service links you to local information and referrals, which has a list of all your community resources. State what you need and this will help match you to the appropriate resource.

*This publication uses "he", "his", or "him" to represent children of both genders

\section{References:}

Agency for Health Care Administration: About Florida Medicaid http://www.fdhc.state.fl.us/Medicaid/index.shtml

Florida KidCare: 1-888-540-5437 Toll Free http://www.floridakidcare.org

Grandparent Resource Center, New York City

Department for Aging. For Grandparents Raising Grandchildren: A Series of Workshops to Help You Cope.

Grandparent Resource Center

NYC Department for the Aging

2 Lafayette Street

New York, NY 10007-1392

(212) 442-1094 or (212) 442-1100
GrandsPlace - Resources and Information: Financial Help Available to Those Raising Grandchildren:

http://www.grandsplace.com/gp1/moneyassist.ht $\underline{\mathrm{ml}}$

Kinship Support Center, University of South Florida School of Social Work. http://www.cas.usf.edu/ krisman/

Kinship Support Center, University of South Florida School of Social Work. Relative Caregiver Program, Department of Children and Families.

http://www.cas.usf.edu/ krisman/Relativecaregiv erfactsheet.htm

MyFlorida.com. Florida Partnership for School Readiness.

http://www.myflorida.com/myflorida/governmen t/governorinitiatives/schoolreadiness/

Williams, D. (2000). Grandparents raising our children's children. University of Idaho Cooperative Extension. Moscow, ID: Ag Communications .

For more information on any of the above, call your local Extension Office. 